\title{
IDŐJÁRÁS
}

Quarterly Journal of the Hungarian Meteorological Service

Vol. 125, No. 3, July-September, 2021, pp. 419-430

\section{Evapotranspiration estimation at the Kis-Balaton wetland}

\author{
Angela Anda*, László Menyhárt, and Brigitta Simon \\ Hungarian University of Agriculture and Life Sciences, Georgikon Campus of Keszthely \\ Corresponding author's e-mail*:
}

*Corresponding author E-mail: anda.angela@uni-mate.hu

(Manuscript received in final form March 31, 2020)

\begin{abstract}
Evapotranspiration rate, $E T_{a}$ and vegetation composition strongly influence the water budget of wetland impacting available water and water resource management. One of the goals of this study was to estimate the areal $E T_{a}$ of the Kis-Balaton wetland, KBW (natural ecosystem) between 1997 and 2012. This time period was free of any human intervention. $E T_{a}$ was accounted for different vegetation classes through the multiplication of the reference evapotranspiration, $E T_{0}$ by previously determined crop coefficients in each vegetation/open water classes. Besides common reed and cattail, five other groups were separated, including open water as an independent class. The evapotranspiration sums were strongly impacted by annual mean air temperature, $T_{a}$. One degree increment in annual average $T_{a}$ will increase the yearly $E T_{a}$ sums in about $100 \mathrm{~mm}$. The yearly areal $E T_{a}$ of KBW ranged from $737.08 \mathrm{~mm}$ to $896.63 \mathrm{~mm}$ with an average of $802.07 \mathrm{~mm}$ during the 16-year study.
\end{abstract}

\section{Introduction}

Crops, including wetlands, under the impact of solar radiation are influenced by such variables as temperature, water transport processes, crop growth, and production (Burba et al., 1999). Partitioning of radiation and actual evapotranspiration, $E T_{a}$ are strongly associated with the stage of vegetation.

Among others, Abtew and Obeysekera (1995) and Allen et al. (1998) discussed the methodology available for wetland's $E T_{a}$ estimations. These wetland's areal $E T_{a}$ approximations are similar to those of used in $E T_{a}$ calculations of arable crops. Two options include direct measurements (lysimeter use, energy balance Bowen ratio, and/or eddy covariance techniques) and modeling approach. 
The main limitations of direct measurements are the high cost of lysimeter maintenance and difficulties in their operation for other crops than wetlands (Valiantzas, 2006; Zhou and Zhou, 2009). This method also requires an expert laboratory (Allen et al., 2011; Wang and Dickinson, 2012). In everyday practice, to get $E T_{a}$, crop coefficients, $K_{c}$ are multiplied by reference evapotranspiration, $E T_{0}$. Limited generalizability of $K_{c}$ exists from plant side, as types and distribution of crops differ greatly from place to place (Drexler et al., 2004). Parallel with this assumption, different kinds of microclimatological models use a large number of hardly accessible inputs (meteorological and canopy surface data).

Anthropogenic interventions have modified the water level of Lake Balaton during the past two centuries. Two hundred years before, the establishment of the sluice of Sió canal and the extension of agricultural land declined the lake's water level drastically, causing serious water quality issues, mainly in the Keszthelybay. To mitigate water quality deterioration, a new reconstruction project, the socalled Kis-Balaton Water Protection System (KBWS) was started at the end of the last century. Previously, severe cyanobacterial blooms deteriorated the water quality of the lake, that was published by Tátrai et al., (2000). Two steps (I and II) were launched as the reconstruction of the Kis-Balaton wetland (KBW). The first step was completed in 1985, while an eutrophic pond (Hídvégi pond) was created by five-step flooding (Korponai et al., 2010). The Hídvégi pond retained the nutrient loads causing overall improvement of the Balaton's water quality (Hatvani et al., 2011). Phase II (Fenéki pond) operated the water level management of the wetland ecosystem synchronizing different habitats to avoid different conflicts. Reconstruction of KBWS was finished in 2016; an area is partly flooded, while other regions remained "untouched" habitats.

The geographical location of the study site, the Carpathian Basin which comprises Lake Balaton and the surrounding extended marshland, makes this region extremely vulnerable. Temperate zone formed in the basin has highly variable inter- and intra-annual precipitation and $E T_{a}$. This region is expected to have severe episodic droughts and floods, creating significant hydrologic lesions in response to human climate modification. In addition to weather variability, the on-site wetland ecosystems have little seasonal variability in green leaf area despite large seasonal variation in $E T_{a}$. A similar tendency was observed by Garbulsky et al. (2008) and Anderson et al. (2012) for Mediterranean wetlands. Due to these combined environmental specialties of temperate zone wetlands, attention was paid to improve the understanding of their $E T_{a}$ peculiarities and their relevant controlling factors (weather variables and crop features). Wetlands differ in their energy regimes and exchange processes due to extent, fluctuating water levels, vegetation types, and geographical positions (Kellner, 2001). Therefore, on-site determined $E T_{a}$ on daily timescale seems to be not appropriate to answer the many-sided questions relating to wetland's $E T_{a}$ (Admiral et al., 2006). One part of the study was dedicated to these local $E T_{a}$ concerns on such a natural ecosystem as KBW. The reason for studying the selected period (1997-2012) was 
the uninterrupted phase in the life of the KBW. There was no human intervention during this time; the ecosystem could be treated as a natural one. This phenomenon is not common in the history of KBW from the end of the 19th century.

\section{Materials and methods}

A 16-year-long areal evapotranspiration study was conducted at the KBW, and the Agrometeorological Research Station (ARS) of Keszthely (latitude: $46^{\circ} 44^{\prime}$ $\mathrm{N}$, longitude: $17^{\circ} 14^{\prime} \mathrm{E}$, elevation: $124 \mathrm{~m}$ above sea level), Hungary. This meteorological station belongs to the observational network of the Hungarian Meteorological Service. A QLC-50 climate station (Vaisala, Helsinki, Finland) with a pyranometer (Kipp \& Zonen Corp., Delft, the Netherlands) is operational at the ARS. Combined air temperature, $T_{a}$ and humidity sensors are placed at a standard height of $2 \mathrm{~m}$ above the surface level. Signals from meteorological sensors are collected every 2 seconds, and 10-min averages are logged. Data of the station were used in both ecosystem parts, including soybean.

$K_{c}$ of dominant macrophytes of KBW were measured previously (20052011) in the growing chambers of Thornthwaite-Mather type compensation evapotranspirometers with unlimited water supply. The surface area of growing chambers was $4 \mathrm{~m}^{2}$, with a depth of $1 \mathrm{~m}$. These containers were settled at the meteorological station located on the northern edge of the KBW. Daily water losses were expressed as a residual member of the water budget equation. Later on, based on these measured evapotranspirations, the $K_{c}$ of different macrophytes was expressed. More details on this experiment were published in Anda et al. (2014). (The same instruments were used in the determination of soybean $E T_{a}$ between 2017 and 2018; see also Section 2.1).

Wetland maps of the KBW were produced by the Central- and WestTransdanubian Water Directorate. To produce digital orthophotos, triangulation was used to get the absolute orientation elements of the aerial photographs. A high resolution digital elevation model (DEM) transformed the original images into orthogonally projected images (Winkler, 2004) with a final pixel size of $0.5 \mathrm{~m}$. The long-term data were analyzed by a pixel-based approach in the Environment for Visualizing Images, ENVI version 4.7 software package (ITT, 2009). The used classification method was the maximum likelihood to get the main classes of the sample area (Fenéki pond). Training areas for the classification were selected from field observations. To draw the vegetation map, ArcMap version 9.3.1 software (ESRI User Manual 2009, CA, US) was applied. See more details in Anda et al. (2014).

The $E T_{a}$ of Fenéki pond was estimated by multiplying the $E T_{o}$ with the $K_{c}$ of the related macrophyte class and by accounting the cover ratio of that class as follows: 


$$
E T_{a}=\frac{\sum_{i=1}^{6}\left(E T_{0} K_{c a i} A_{i}\right)}{\sum_{i=1}^{6} A_{i}},
$$

where $A$ is the area covered by the macrophyte and open water classes (1-6).

\subsection{Statistics}

The distribution of each $E T_{a}$ series was checked by the Shapiro-Wilks test for normality. Square root transformation was performed to satisfy the assumption of normality. Long-term annual $E T_{a}$ totals with a normal distribution $\left(\mathrm{mm} \mathrm{year}^{-1}\right)$ were analyzed by a two-tailed t-test. All tests were carried out with SPSS Statistics version 17.0 software (IBM Corp., New York, USA).

\section{Results and discussion}

\subsection{Composition of $K B W$}

Based on the maps (ortophotograps) of the Hungarian Water Authority, the composition of the wetland was established between 1997 and 2012 (Fig. 1). Six classes were distinguished containing one open water and five macrophytes (Crundell, 1986) as follows:

Class 1. Tall emergent macrophytes: weed and two cattail species. As there was no significant difference in $E T_{a}$ (including $C_{k}$ ) between the reed and cattail, they were put together in the same category.

Class 2. Leafy emergent macrophytes: Three species of sedge included in the second class of macrophytes.

Class 3. Woody shrub: willow.

Class 4. Grassland: fescue, French ryegrass, foxtail.

Class 5. Woody deciduous: alder, cottonwood.

Class 6. Open water: incorporating seaweed.

The ratio and composition of the classes with their spatial ranges are presented in Table 1.

Due to the presence of seaweed in the water of Kis-Balaton, to derive the accurate evaporation, the Class A pan evaporation was modified, filling the pans with seaweed and littoral sediments (Anda et al., 2018). About 15-20\% increase in the "filled" pan evaporation was measured due to the above intervention. 
The first two categories dominated the wetland canopy $(40 \%+30 \%=70 \%)$. Outside of these two dominant classes, there was only one (Class 5), in which the cover ratio of a given class exceeded $10 \%$. The cover percentage of all other groups fell well below $10 \%$.

Table 1. Composition of KBW using vegetation and open water classes in the period of 1997-2012

\begin{tabular}{lllllll}
\hline \hline Classes & Type of habitat & $\begin{array}{l}\text { Typical species } \\
\text { (Latin names) }\end{array}$ & $\begin{array}{l}\text { Common } \\
\text { names }\end{array}$ & $\begin{array}{l}\text { Mean } \\
\mathbf{\%}\end{array}$ & $\begin{array}{l}\text { Cover } \\
\text { Min } \\
\text { \% }\end{array}$ & $\begin{array}{l}\text { Max } \\
\text { \% }\end{array}$ \\
\hline \hline Class 1 & $\begin{array}{l}\text { Tall emergent } \\
\text { macrophytes }\end{array}$ & $\begin{array}{l}\text { Phragmites australis, } \\
\text { Typha angustifolia, Typha } \\
\text { latifolia }\end{array}$ & $\begin{array}{l}\text { reed } \\
\text { cattail }\end{array}$ & 40 & 39 & 42 \\
\hline Class 2 & $\begin{array}{l}\text { Leafy emergent } \\
\text { macrophytes }\end{array}$ & $\begin{array}{l}\text { Carex acutiformis, Carexe } \\
\text { lata, Carex riparia }\end{array}$ & sedge & 30 & 27 & 33 \\
\hline Class 3 & Woody shrub & Salix cinerea, Salix alba & willow & 5 & 4 & 6 \\
\hline Class 4 & $\begin{array}{l}\text { Grassland } \\
\text { Festuca rupicola, } \\
\text { Arrhenatherum elatior, }\end{array}$ & $\begin{array}{l}\text { fescue } \\
\text { French } \\
\text { ryegrass } \\
\text { foxtail }\end{array}$ & 8 & 6 & 9 \\
\hline Class 5 & $\begin{array}{l}\text { Woody } \\
\text { deciduous }\end{array}$ & $\begin{array}{l}\text { Salix fragilis, } \\
\text { Alnus } \text { glutinosa, } \\
\text { Populus tremula }\end{array}$ & $\begin{array}{l}\text { willow } \\
\text { alder } \\
\text { cottonwood }\end{array}$ & 11 & 10 & 11 \\
\hline Class 6 & $\begin{array}{l}\text { Open water } \\
\text { (with submerged } \\
\text { crops) }\end{array}$ & $\begin{array}{l}\text { Ceratophyllum demersum, } \\
\text { Najas marina }\end{array}$ & seaweed & 6 & 6 & 7 \\
\hline
\end{tabular}




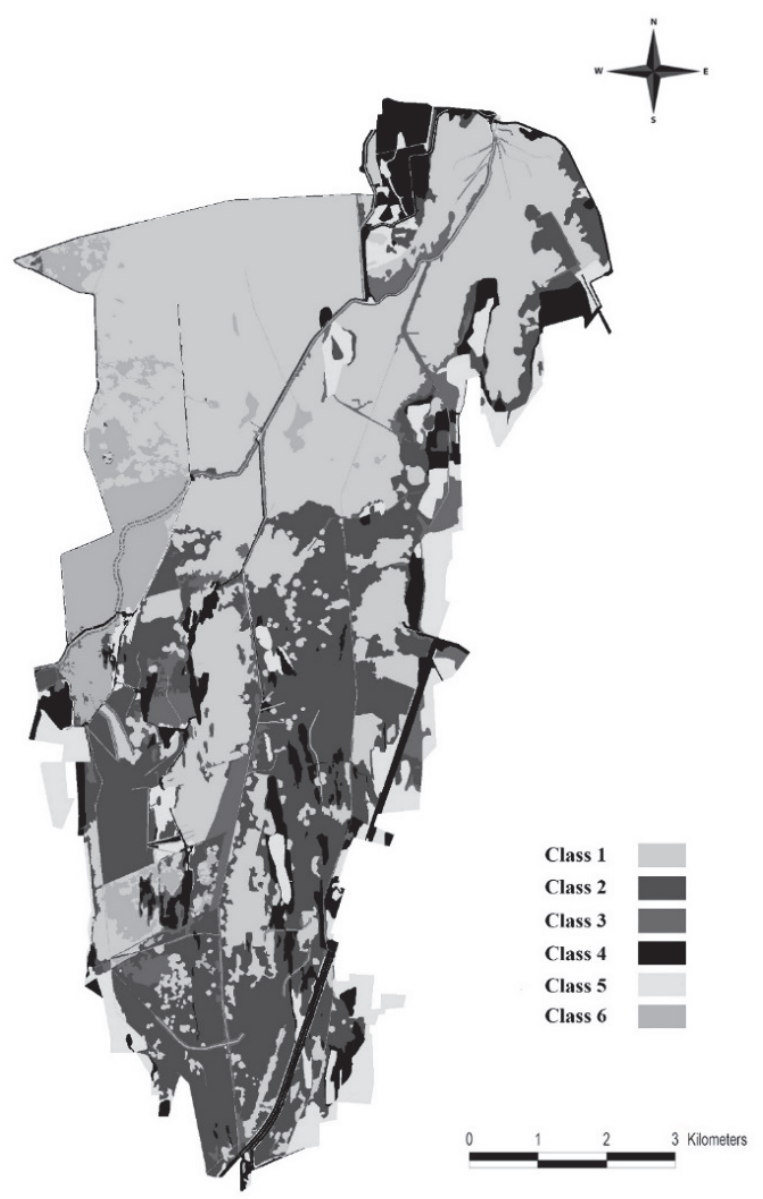

Fig. 1. Composition of macrophyte and open water classes in the KBW (Anda et al., 2015). (class 1: tall emergent macrophytes; class 2: leafy emergent macrophytes; class 3 : woody shrub; class 4: grassland; class 5: woody deciduous; class 6: open water \pm seaweed)

\subsection{ET $T_{a}$ of the wetland with $T_{a}$}

On the basis of daily on-site measurements in evapotranspirometer/A pan and calculated $E T_{0}$ (Allen et al., 1998), their ratios, the $C_{k}$ /pan coefficients were derived for class 1, class 2, and class 4 from 2005 to 2011. In the remaining two vegetation classes (class 3, class 5) data of Irmak et al. (2013) were adopted. The actual $E T_{a}$ equals to the multiplication of $E T_{0}$ by $C_{k}$. A detailed description of the process and $C_{k}$ results were published in Anda et al. (2014).

Long-term daily mean $E T_{a}$ of six wetland classes with different covers ranged from 2.87 (class 5) to 4.04 (class 1) $\mathrm{mm} \mathrm{day}^{-1}$, with the maximum of $4.45 \mathrm{~mm}^{\text {day }}{ }^{-}$ ${ }^{1}$ (class 1) in 2012 and minimum of $2.62 \mathrm{~mm} \mathrm{day}^{-1}$ (class 5) in 2005 (Table 2). The highest $E T_{a}$ was always observed in reed canopy (class 1 ) and not in open water. Open water evaporation can also limited by the temperature profile over the water surface. When the water surface is colder than the surrounding air, and there is only weak wind, a cold cap can limit the evaporation processes, since in the cold 
air, the atmospheric humidity is higher. Although the derived 16-year daily mean $E T_{a}$ of Fenéki pond (3.63 $\left.\mathrm{mm} \mathrm{day}^{-1}\right)$ was closer to the open water evaporation (3.66 $\mathrm{mm} \mathrm{day}^{-1}$ ) than that of the $E T_{a}$ of classes with different crop covers. It is worth to remark that the cover of open water in KBW ranges between 6 and 7\% only. The lowest daily mean $E T_{a}$ was always observed in woody deciduous class, while the highest ones were in the two dominant macrophyte classes (class 1 and class 2). These two latter categories' results were comparable with that of $4.4 \mathrm{~mm}$ day $^{-1}$ revealed by Lenters et al. (2011) for reed and cattail dominated wetland in Nebraska, USA, for almost the same environmental conditions as at the KBW. Similar daily mean $E T_{a}$ results of $4.3 \mathrm{~mm}^{\text {day }}{ }^{-1}$ were obtained by Irmak et al. (2013) for a riparian plant community for Nebraska, for the same growing site as the previous citation of Lenters et al. (2011) mentions.

Table 2. Daily mean evapotranspiration ( $\mathrm{mm} / \mathrm{day}$ ) of six the wetland classes with different covers and areal evapotranspiration of the whole Fenéki pond between 1997 and 2012

\begin{tabular}{rrrrrrrrr}
\hline \hline \multicolumn{1}{c}{ Class 1 } & Class 2 & \multicolumn{2}{c}{$\begin{array}{c}\text { Class 3 } \\
\text { [mm day }\end{array}$} & Class 4 & Class 1 & Class 6 & \multicolumn{2}{c}{$\begin{array}{l}\text { Fenéki } \\
\text { pond }\end{array}$} \\
\hline \hline 1997 & 3.87 & 3.36 & 3.04 & 3.13 & 2.77 & 3.53 & 3.47 \\
1998 & 3.76 & 3.25 & 2.97 & 3.05 & 2.68 & 3.42 & 3.38 \\
1999 & 3.81 & 3.29 & 2.99 & 3.07 & 2.71 & 3.45 & 3.41 \\
2000 & 4.36 & 3.77 & 3.42 & 3.53 & 3.09 & 3.96 & 3.92 \\
2001 & 4.10 & 3.52 & 3.19 & 3.30 & 2.86 & 3.70 & 3.66 \\
2002 & 4.22 & 3.61 & 3.24 & 3.37 & 2.98 & 3.77 & 3.77 \\
2003 & 4.32 & 3.73 & 3.40 & 3.49 & 3.09 & 3.92 & 3.89 \\
2004 & 3.75 & 3.27 & 3.01 & 3.06 & 2.69 & 3.44 & 3.39 \\
2005 & 3.71 & 3.20 & 2.88 & 2.99 & 2.62 & 3.35 & 3.33 \\
2006 & 3.83 & 3.29 & 2.98 & 3.07 & 2.71 & 3.44 & 3.43 \\
2007 & 4.24 & 3.64 & 3.30 & 3.41 & 2.97 & 3.81 & 3.80 \\
2008 & 4.05 & 3.51 & 3.19 & 3.28 & 2.88 & 3.68 & 3.65 \\
2009 & 4.07 & 3.53 & 3.24 & 3.31 & 2.91 & 3.72 & 3.68 \\
2010 & 3.75 & 3.21 & 2.92 & 3.01 & 2.64 & 3.36 & 3.36 \\
2011 & 4.36 & 3.80 & 3.46 & 3.55 & 3.13 & 4.00 & 3.94 \\
2012 & 4.45 & 3.86 & 3.54 & 3.61 & 3.20 & 4.05 & 4.02 \\
\hline Mean & $\mathbf{4 . 0 4}$ & $\mathbf{3 . 4 9}$ & $\mathbf{3 . 1 7}$ & $\mathbf{3 . 2 7}$ & $\mathbf{2 . 8 7}$ & $\mathbf{3 . 6 6}$ & $\mathbf{3 . 6 3}$ \\
\hline
\end{tabular}


During the observation period, the 16-year annual $E T_{a}$ totals of different classes ranged from 745.98 (class 5) to $974.81 \mathrm{~mm}$ (class 1) with a weighted average of $896.63 \mathrm{~mm}$ for the Fenéki-pond. The most important statistical characteristics are presented in Fig. 2. According to the daily mean $E T_{a}$ results of vegetation and open water classes, the highest yearly $E T_{a}$ sums were observed in reed (cattail) followed by the open water, which result was very close to spatial $E T_{a}$ sum of the whole Fenéki pond. In case of Fenéki-pond, the annual weighted mean $E T_{a}$ of warm years increased with $11.45 \%(\mathrm{p}<0.001)$ in comparison to cool year's $E T_{a}$ water losses, suggesting that almost $100 \mathrm{~mm}$ difference in wetland's $E T_{a}$ was manifested in favor of warm periods.

On the basis of the 16-year study, the largest water consumer in the KisBalaton was the reed and cattail (class 1), occupying almost half of the wetland area (Fig. 3). The second in line is the sedge (class 2), contributing at about a third of the total water use. Annual mean water losses (ET $T_{a}$ or evaporation) of all the other vegetation/open water classes contributed less than $10 \%$.

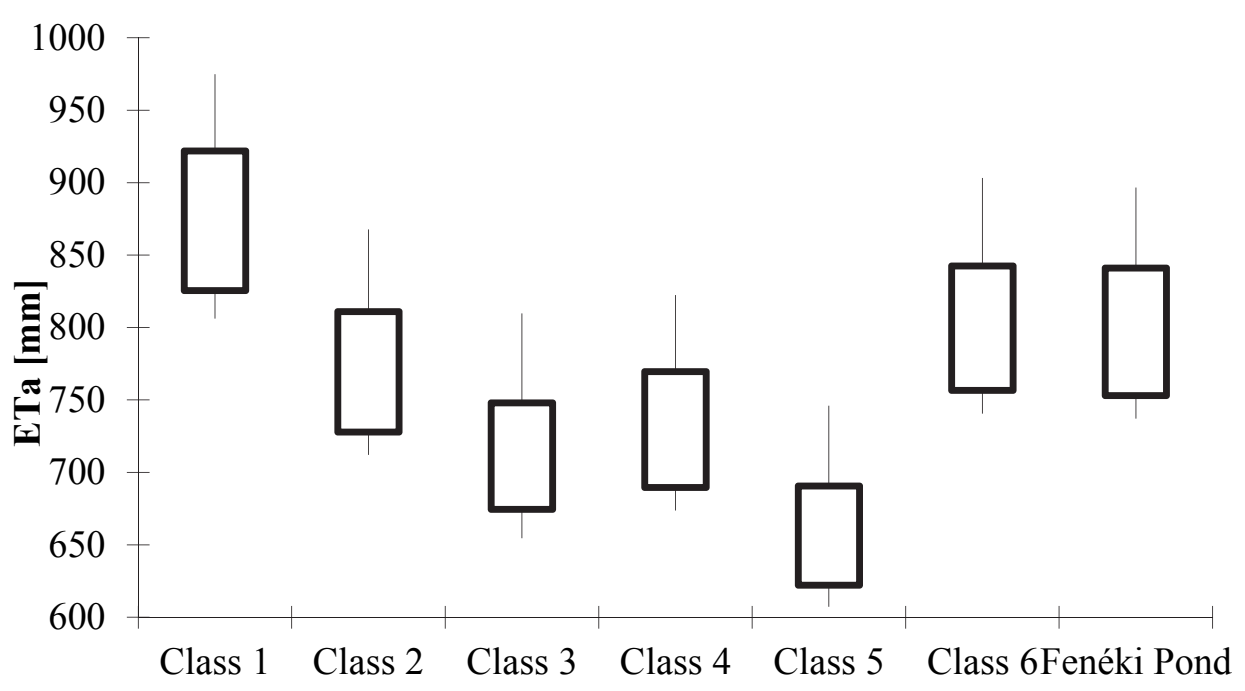

Fig. 2. Box-plot for the annual evapotranspiration totals, $E T_{a}$ in different vegetation and open water classes between 1997 and 2012. The bottom and top of the boxes represent the 25 th and 75 th percentiles. The vertical lines that end in horizontal strokes above and below each box are from the upper and lower hinges to the upper and lower adjacent values. 


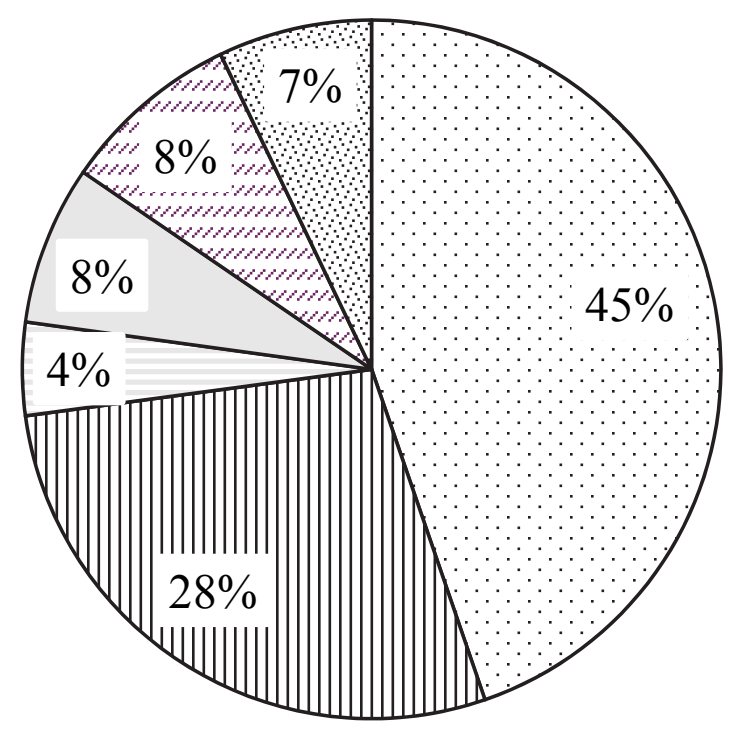

Fig. 3. Contribution of different vegetation/open water classes to the evapotranspiration of the Fenéki pond.

Yearly mean $\mathrm{T}_{\mathrm{a}}$ of KBW was $10.8^{\circ} \mathrm{C}$ between 1997 and 2012. The 1971 to 2000 climate norm of $10.3^{\circ} \mathrm{C}$ was half-degree lower than that of the annual mean $\mathrm{T}_{\mathrm{a}}$ during the investigation period. Out of sixteen years studied, seven cool $\left(T_{a}<10.8^{\circ} \mathrm{C}: 1997,1998,1999,2004,2005,2005,2010\right)$ and nine warm years $\left(T_{a}>10.8^{\circ} \mathrm{C}: 2000,2001,2002,2003,2007,2008,2009,2011,2012\right)$ were distinguished, which might be decisive for the wetland's $E T_{a}$. The difference in annual average $T_{a}$ between cool $\left(10.1^{\circ} \mathrm{C}\right)$ and warm years $\left(11.3^{\circ} \mathrm{C}\right)$ equalled to $1.2^{\circ} \mathrm{C}(\mathrm{p}<0.001)$. It is worth to notice that all warm years were registered after 2000.

To evaluate the potential impact of annual mean $T_{a}$ versus $E T_{a}$ total, linear regression was fitted (Fig. 4). Based on the slope, $1{ }^{\circ} \mathrm{C}$ increment in annual $T_{a}$ significantly increased the $E T_{a}$ totals by $61.7 \mathrm{~mm}$, with a relatively low RMSE of $23.9 \mathrm{~mm} /$ year. The scatter in the data was higher at cooler years. 
1997-2013

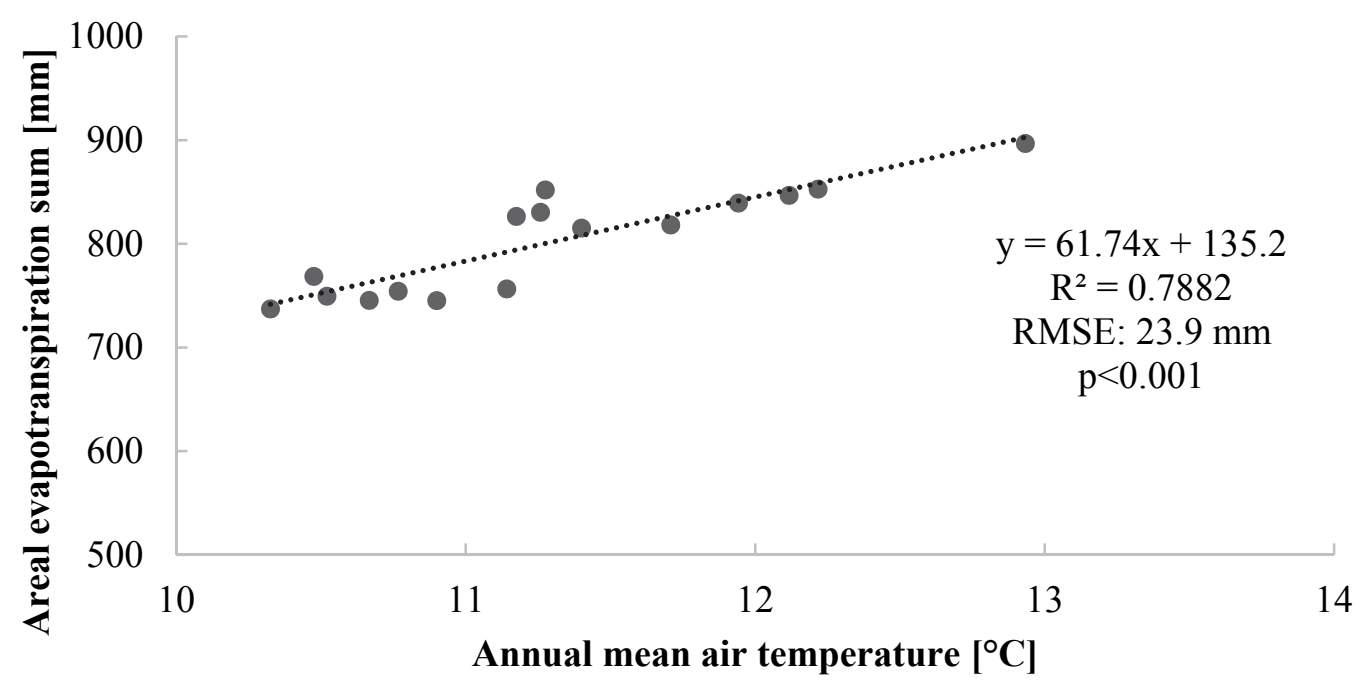

Fig. 4. Regression between annual mean air temperatures vs areal evapotranspiration totals at the KBW between 1997 and 2012.

\section{Conclusions}

In the KBW, the climatic norm (1971-2000) of annual precipitation sum is $634.2 \mathrm{~mm}$ with the wettest and driest monthly precipitation sums of $78.5 \mathrm{~mm}$ in July and $31.1 \mathrm{~mm}$ in January, respectively. Comparison between long-term annual $\mathrm{ET}_{\mathrm{a}}$ sums and climate norm of precipitation confirmed only $70.7 \%$ of the $E T_{a}$ entering by precipitation at the KBW. Other inputs are also needed to balance the water budget of the wetland. The governing terms of a wetland water balance are the $E T_{a}$ and the precipitation (Soja et al., 2013), making the system vulnerable to the negative impacts of the climatic change through variable rainfall events. Monitoring these governor factors would help for water authorities to mitigate issues related to the water level of KBW and Lake Balaton that are embedding on the system due to upcoming climate change.

Acknowledgements: The publication is supported by the EFOP-3.6.3-VEKOP-16-2017-00008 project. The project is co-financed by the European Union and the European Social Fund. 


\section{References}

Abtew, $W$. and Obeysekera, J., 1995: Lysimeter study of evapotranspiration of cattails and comparison of three estimation methods. Trans. ASAE 38, 121-129. https://doi.org/10.13031/2013.27820

Admiral, S.W., Lafleur, P.M., and Roulet, N.T., 2006: Controls on latent heat flux and energy partitioning at a peat bog in eastern Canada. Agric. Forest Meteor. 140,308-321. https://doi.org/10.1016/j.agrformet.2006.03.017

Allen, R. G., L. S. Pereira, T. A. Howell, Jensen, M. E., 2011: Evapotranspiration information reporting: I. Factors governing measurement accuracy. Agric. Water Manage. 98, 899-920. https://doi.org/10.1016/j.agwat.2010.12.015

Allen, R.G., Pereira, L.S., Raes, D., and Smith, M., 1998: Crop Evapotranspiration: Guidelines for Computing Crop Requirements. FAO Irrigation and Drainage Paper 56 FAO, Rome, Italy.

Anda, A., Simon, B., Soós, G., Menyhárt, L., Teixeira da Silva, J. A., Kucserka, T., 2018: Extending Class A pan evaporation for a shallow lake to simulate the impact of littoral sediment and submerged macrophytes: a case study for Keszthely Bay (Lake Balaton, Hungary). Agric. Forest Meteorol. 250-251, 277-289.

https://doi.org/10.1016/j.agrformet.2018.01.001

Anda, A., Soos, G., Teixeira da Silva, J.A., and Kozma-Bognár, V., 2015: Regional evapotranspiration from a wetland in Central Europe, in a 16-year period without human intervention. Agric. Forest Meteorol. 205, 60-72. https://doi.org/10.1016/j.agrformet.2015.02.010

Anda A., Teixeira da Silva J.A., and Soos, G., 2014: Evapotranspiration and crop coefficient of the common reed at the surroundings of Lake Balaton, Hungary. Aquatic Bot. 116, 53-59. https://doi.org/10.1016/j.aquabot.2014.01.008

Anderson, R.G., Yufang, J., and Goulden, M.L., 2012: Assessing regional evapotranspiration and water balance across a Mediterranean montane climate gradient. Agric. Forest Meteorol. 166-167, 1022. https://doi.org/10.1016/j.agrformet.2012.07.004

Burba, G.G., Verma, S.B., and Kim, J., 1999: Surface energy fluxes of Phragmites australis in a prairie wetland. Agric. Forest Meteor. 94: 31-51. https://doi.org/10.1016/S0168-1923(99)00007-6

Crundell, M. E.. 1986: A Review of hydrophyte evapotranspiration. Rev. Hydrobiol. Trop. 19, 215-232.

Drexler, J.Z., Snyder. R,L, Spano, D., and Paw U, K.T., 2004: A review of models and meteorological methods used to estimate wetland evapotranspiration. Hydrol. Proc. 18, 2071-2101. https://doi.org/10.1002/hyp.1462

Garbulsky, M.F., Penuelas, J., Papale, D., and Filella, I. 2008. Remote estimation of carbon dioxide uptake by a Mediterranean forest. Global Change Biol. 14, 2860-2867. https://doi.org/10.1111/j.1365-2486.2008.01684.x

Hatvani, I.G., Kovács, J., Székely Kovács, I., Jakusch, P., and Korponai, J. 2011. Analysis of long-term water quality changes in the Kis-Balaton Water Protection System with time series-, cluster analysis and Wilks' lambda distribution. Ecol. Engineer. 37, 629-635. https://doi.org/10.1016/j.ecoleng.2010.12.028

Irmak S, Kabenge I, Rudnicka D, Knezevic S, Woodward D, and Moravek, M., 2013. Evapotranspiration crop coefficients for mixed riparian plant community and transpiration crop coefficients for common reed, cottonwood and peach-leaf willow in the Platte River Basin. Nebraska-USA. $J$. Hydrol. 481,177-190. https://doi.org/10.1016/j.jhydrol.2012.12.032

ITT, 2009: ENVI Program Package 2009. ITT corporation ENVI 4.7 software, 1133 Westchester Avenue, White Plains, NY 10604, USA.

Lenters, J.D., Cutrell, G.J., Istanbulluoglu, E., Scott, D.T., Herrman, K.S., Irmak, A., and Eisenhauer, D.E., 2011: Seasonal energy and water balance of a Phragmites australis-dominated wetland in the Republican River basin of south-central Nebraska (USA). J. Hydrol. 408, 19-34. https://doi.org/10.1016/j.jhydrol.2011.07.010

Kellner, E., 2001: Surface energy fluxes and control of evapotranspiration from a Swedish Sphagnum mire. Agric. Forest Meteorol. 110:101-123. https://doi.org/10.1016/S0168-1923(01)00283-0

Korponai, J., Braun, M., Buczkó, K., Gyulai, I., Forró, L., Nedli, J., and Papp, I. 2010. Transition from shallow lake to a wetland: a multi-proxy case study in Zalavari Pond, Lake Balaton, Hungary. Hydrobiologia 641, 225-244. https://doi.org/10.1007/s10750-009-0087-0 
Soja G., Züger J., Knoflacher M., Kinner, P., and Soja, A.M., 2013. Climate impacts on water balance of a shallow steppe lake in eastern Austria (Lake Neusiedl). $J$ Hydrol. 480,115-124. https://doi.org/10.1016/j.jhydrol.2012.12.013

Tátrai, I., Mátyás, K., Korponai, J., Paulovits, G., and Pomogyi, P., 2000: The role of the Kis-Balaton Water Protection System in the control of water quality of Lake Balaton. Ecol. Eng. 16, 73-78. https://doi.org/10.1016/S0925-8574(00)00091-4

Valiantzas, J.D., 2006: Simplified versions for the Penman evaporation equation using routine weather data. J. Hydrol. 331, 690-702. https://doi.org/10.1016/j.jhydrol.2006.06.012

Zhou, L. and Zhou, G.S., 2009: Measurement and modelling of evapotranspiration over a reed (Phragmites australis) marsh in Northeast China. J. Hydrol. 372, 41-47. https://doi.org/10.1016/j.jhydrol.2009.03.033

Wang, K. and Dickinson, R.E., 2012. A review of global terrestrial evapotranspiration: Observation, modeling, climatology, and climatic variability, Rev. Geophys., 50, RG2005, doi:10.1029/2011RG000373. https://doi.org/10.1029/2011RG000373

WMO Report, 1975: Drought and Agriculture. WMO Techn. Note No. 138.

Winkler, P., 2004: The national orthophoto program of Hungary completed under strict quality control. The International Archives of the Photogrammetry, Remote Sens. Spatial Inform. Sci. 34. FÖMI, Budapest. 